\title{
First inventory of benthic mollusks associated with the reef ecosystems of Morro de São Paulo on Tinharé Island in northeastern Brazil
}

\author{
Silvio Felipe Barbosa Lima ${ }^{1,2,3}$, Bianca Vieira Lima ${ }^{1}$, Evandro Cosmo Abreu ${ }^{1}$, Geraldo Semer \\ Pomponet Oliveira ${ }^{4}$, Rudá Amorim Lucena ${ }^{5}$, Luana Marina de Castro Mendonça ${ }^{6,7}$, Jéssica Prata $^{5}$ \& \\ J. Weverton S. de Souza ${ }^{8}$ \\ ${ }^{1}$ Universidade Federal de Campina Grande, Centro de Formação de Professores, Unidade Acadêmica \\ de Ciências Exatas e da Natureza, Rua Sérgio Moreira de Figueiredo, Casas Populares, 58900-000, \\ Cajazeiras, PB, Brasil. \\ ${ }^{2}$ Universidade Federal da Paraiba - Campus I, Centro de Ciencias Exatas e da Natureza, Departamento \\ de Sistemática e Ecologia, Programa de Pós-Graduação em Ciências Biológicas (Zoologia), Cidade \\ Universitária, 58051-900, João Pessoa, PB, Brasil. \\ ${ }^{3}$ Universidade Federal da Paraíba - Campus II, Centro de Ciências Agrárias, Departamento de Ciências \\ Biológicas, Programa de Pós-Graduação em Biodiversidade, Cidade Universitária, 58397-000, \\ Areia, PB, Brasil. \\ ${ }^{4}$ Pesquisador autônomo, Caixa Postal 4444, 40375-973, Salvador, BA, Brasil. \\ ${ }^{5}$ Universidade Federal da Paraíba - Campus I, Centro de Ciencias Exatas e da Natureza, Departamento \\ de Sistemática e Ecologia, Laboratório de Invertebrados Paulo Young, Cidade Universitária, 58051-900, \\ João Pessoa, PB, Brasil. \\ ${ }^{6}$ Universidade Federal de Sergipe, Centro de Ciências Biológicas e da Saúde, Departamento de Biologia, \\ Laboratório de Bentos Costeiro, Cidade Universitária Prof. José Aloísio de Campos, Avenida Marechal \\ Ronodon, Jardim Rosa Elze, 49100-000, São Cristóvão, SE, Brasil. \\ ${ }^{7}$ Universidade Federal do Paraná, Departamento de Zoologia, Laboratório de estudos de Cnidaria e Bryozoa, \\ Avenida Coronel Francisco Heráclito dos Santos, Jardim das Américas, 81530-000, Curitiba, PR, Brasil. \\ ${ }^{8}$ Universidade Estadual de Campinas, Instituto de Biologia, Programa de Pós-Graduação em Ecologia, Avenida \\ Bertrand Russel, Cidade Universitária Zeferino Vaz, Barão Geraldo, 13083-865, Campinas, SP, Brasil. \\ *Corresponding author: Silvio Felipe Barbosa Lima, e-mail: sfblima@gmail.com
}

LIMA, S. F. B., LIMA, B. V., ABREU, E. C., OLIVEIRA, G. S. P., LUCENA, R. A., MENDONÇA, L. M. C., PRATA, J., SOUZA, J. W. S. First inventory of benthic mollusks associated with the reef ecosystems of Morro de São Paulo on Tinharé Island in northeastern Brazil. Biota Neotropica. 19(4): e20190745. http://dx.doi.org/10.1590/1676-0611-BN-2019-0745.

\footnotetext{
Abstract: The reef ecosystems of Morro de São Paulo are located in the Tinharé-Boipeba Environmental Preservation Area which was established in 1992 in the state of Bahia, Brazil. Despite this area has been created more than two decades ago, no study has provided knowledge on the invertebrate biodiversity associated with such reef ecosystems. The present investigation provides the first inventory of benthic mollusks associated with the reef ecosystems of Morro de São Paulo based on the collection of living specimens and fresh empty as well as some worn shells. Mollusks were sampled in January 2015 and August 2016 through intensive searches from the intertidal to shallow subtidal habitats of the reefs on three beaches of Morro de São Paulo. Taxonomic richness and biodiversity indices were analyzed. This rapid assessment of the malacofauna resulted in the determination of 84 species belonging to 44 families of gastropods as well as 13 species belonging to eight families of bivalves and one chiton (total: 98 species). Species richness was numerically dominated by members of the subclass Caenogastropoda. The families with the largest number of species were Ranellidae (5), Muricidae (6) and Marginellidae (7). Conus regius, Cypraecassis testiculus, Lobatus goliath, Strombus pugilis, Tonna galea, Turbinella laevigata and Vasum cassiforme are extremely vulnerable macrospecies in the region due to their commercial importance. Comparisons of the malacofauna composition between the study site and Abrolhos Bank were made from data published for this region. ACE and CHAO 1 estimated 133 mollusk species for the region. Despite the rapid assessment, the number of species discovered in the study area approached $73.6 \%$ of the estimated total number. The considerable number of mollusk species found in a relatively small area with insufficient sampling underscores the importance of the reef ecosystems of Morro de São Paulo as a one priority area for conservation on the coast of the state of Bahia, Brazil, for which the species richness of other invertebrate groups is virtually unknown.

Keywords: Alpha diversity, malacofaunal composition, Gastropoda, Bivalvia, Polyplacophora.
} 
Lima, S.F.B. et al.

\title{
Primeiro inventário de moluscos bentônicos associados aos ecossistemas recifais do Morro de São Paulo na Ilha Tinharé, nordeste do Brasil
}

\begin{abstract}
Resumo: Os ecossistemas recifais do Morro de São Paulo estão na área de proteção ambiental Tinharé-Boipeba, a qual foi estabelecida em 1992 no estado da Bahia, Brasil. Apesar desta área ter sido criada há mais de duas décadas, nenhum estudo foi realizado sobre a biodiversidade de invertebrados associados a tais ecossistemas recifais. Este trabalho representa o primeiro inventário de moluscos bentônicos associados aos ecossistemas recifais do Morro de São Paulo com base na coleta de indivíduos vivos e conchas com superfície íntegra e desgastada. Moluscos foram amostrados em janeiro de 2015 e agosto de 2016 através de busca ativa em habitats das regiões entremarés e sublitoral dos ecossistemas recifais nas três praias do Morro de São Paulo. A riqueza taxonômica e índices de biodiversidade foram analisados. O inventário da malacofauna resultou na identificação de 84 espécies pertencentes a 44 famílias de gastrópodes bem como 13 espécies pertencentes a oito famílias de bivalves e um quiton (total: 98 species). A riqueza de espécies foi numericamente dominada por membros da subclasse Caenogastropoda. As famílias com o maior número de espécies foram Ranellidae (5), Muricidae (6) and Marginellidae (7). Conus regius, Cypraecassis testiculus, Lobatus goliath, Strombus pugilis, Tonna galea, Turbinella laevigata e Vasum cassiforme são macroespécies extremamente vulneráveis na região devido a sua importância comercial. A composição malacofaunística da área estudada foi comparada com a do Arquipélago de Abrolhos. ACE e CHAO 1 estimaram 133 espécies de moluscos para a região. Apesar do rápido levantamento, o número de espécies descobertas na área em questão se aproximou em $73.6 \%$ do número total estimado. O considerável número de espécies de moluscos encontradas em uma área relativamente pequena com insuficiente esforço amostral ressalta a importância dos ecossistemas recifais do Morro de São Paulo como uma área prioritária para conservação na costa do estado da Bahia, Brasil, na qual a riqueza de outros grupos de invertebrados é virtualmente desconhecida.

Palavras-chave: Diversidade alfa, composição malacofaunística, Gastropoda, Bivalvia, Polyplacophora.
\end{abstract}

\section{Introduction}

Brazil has about $10,800 \mathrm{~km}$ of coastline $\left(04^{\circ} 52^{\prime} \mathrm{N}\right.$ to $\left.33^{\circ} 45^{\prime} \mathrm{S}\right)$ and a marine area of approximately 3.5 million $\mathrm{km}^{2}$. This coastal zone is among the largest and most important marine ecoregions in the world due to the climatic range, geomorphological variety (MMA 2010) and heterogeneity of ecosystems (Dutra et al. 2005, Rodríguez-Ramírez et al. 2008, Leão et al. 2016). Consequently, the Brazilian marine biome is recognized as an area of high biological importance that harbors a large number of species (MMA 2010).

The state of Bahia, in the northeastern region of the country, has the largest coastal zone in Brazil. This geomorphologically complex area has a variety of coastal environments, with muddy, silty and sandy bottoms, seagrass, coralline algae, reef outcrops, protected bays, mangroves, estuaries and reef ecosystems. Such heterogeneity leads to the formation of a wide variety of benthic habitats that harbor a high richness of invertebrates. Furthermore, the coastal zone of Bahia is recognized as a Brazilian marine biodiversity "hotspot", mainly due to the occurrence of the richest and largest coral reef complex in the South Atlantic. Despite the biological and ecological importance of this coastal zone (Leão \& Ginsburg 1997, Alves \& Cerqueira 2000, Leão 2002, Dutra et al. 2005, Barros et al. 2008, MMA 2010, Ourives et al. 2011, Paz et al. 2012, Cunha et al. 2013, Moura et al. 2015, Paim et al. 2015, Leão et al. 2016, Mazzei et al. 2016, Lucena \& Christoffersen 2017), there remains much to be discovered regarding the biological diversity of its ecosystems, even in the most studied regions between the Abrolhos Archipelago and Tinharé-Boipeba Environmental Protection Area.

A large number of studies have been conducted on cnidarians along the coast of Bahia, demonstrating the biological and ecological importance of its reef complex (Hetzel \& Castro 1994, Leão 1996, Costa Jr. et al. 2000, Leão \& Kikuchi 2001, Castro et al. 2005a, b, Mazzei et al. 2016). In contrast, mollusks are among the groups of marine invertebrates that have been under-investigated in the region. Mollusca is the most specious phylum of marine metazoans, which are widely distributed throughout the world (Bouchet et al. 2002, 2011, 2016) inhabiting all environments from the supralittoral zone to trenches and hydrothermal vents (Moretzsohn et al. 2009, Castro \& Huber 2013).

Despite the need for a greater number of studies, publications have shown that somewhat more is known regarding marine mollusks that inhabit the coastal ecosystems of the state of Bahia. Records of occurrence (Absalão 2005b, Queiroz et al. 2011, 2013, Sales et al. 2011, 2013, 2016, Queiroz \& Sales 2016), associations with other invertebrates (Queiroz et al. 2013), reproductive aspects (Queiroz \& Sales 2013), descriptions of species (Absalão 2002, Lima et al. 2013) as well as the results of ecological studies conducted on tide pools, bays and estuarine systems (Alves et al. 2006, Barros et al. 2008, Ourives et al. 2011, Luz \& Couto 2014) and malacofaunistic surveys are available (Barros 1994, Absalão 2005a, Paz et al. 2012).

The most recent information from malacofauna surveys conducted in the state of Bahia comes from the papers entitled "Survey of the benthic malacofauna of rocky shores of the mesolittoral zone of Plataforma beach" (Paz et al. 2012) and "Mollusks in pools on the Coroa Vermelha reef plateau" (Luz et al. 2014). Knowledge on actual mollusk richness in marine ecosystems is far from being considered satisfactory due to the scarcity of taxonomic studies. This is one of the major challenges to gain a better understanding of ecological dynamics between living organisms and the environment, especially in unique areas, such as the coast of Bahia, due to the current threat to marine life posed by anthropogenic pressures. Thus, the aim of the present study was to document the biodiversity of mollusks in the reef ecosystems of Morro de São Paulo located on Tinharé Island in the state of Bahia, 
northeastern Brazil, which is an underexplored area from the zoological standpoint. To the best of our knowledge, there has been no previous information published on Mollusca in the region.

\section{Material and Methods}

\section{Study area}

The study area is located in the Tinharé-Boipeba Environmental Preservation Area, which was established in 1992. The area has approximately $0.433 \mathrm{~km}^{2}$ and is located between the mouth of the Patos River and the Taperoá Channel (INEMA 2016). Sampling was performed in the intertidal and shallow subtidal zones of Morro de São Paulo (13'22'56.0"S, 38 54'32.1'W), which is located on Tinharé Island in the municipality of Cairú, state of Bahia, northeastern Brazil (Figure 1). Three main beaches are recognized for Morro de São Paulo, each of which covers approximately $300 \mathrm{~m}^{2}$ and has a large influx of tourists. The three beaches studied have reef areas with rather homogeneous characteristics and are located in areas close to tourist accommodations, making them vulnerable to considerable anthropogenic impact. The first and second beaches are more accessible to tourists. The reef ecosystems of the third beach are slightly farther away from the sand strip and are separated by narrow pools that hinder access.

The coastal environment of Morro de São Paulo is a shallowwater habitat characterized mainly by fringing reefs that are exposed during low tide. Such reefs have an irregular, truncated surface cut by channels that give rise to tide pools (Kikuchi et al. 2008). Fringing reefs extend for tens of meters and are close to the beach line, forming discontinuous structures in shallower regions. These ecosystems form habitats composed of mixed patches of sand, gravel bottoms and algal aggregations, as such Halimeda opuntia (Linnaeus) J.V. Lamouroux, 1816; Sargassum polyceratium Montagne, 1837; Lithothamnium sp.; Ulva lactuca Linnaeus, 1753 and Gracilaria caudata J. Agardh, 1852.

\subsection{Sampling, identification and analysis}

The present study was limited to macromollusk species (generally larger than $10 \mathrm{~mm}$ in size) that could be easily sighted in the field. Sampling of the reef ecosystems on the three beaches located in Morro de São Paulo was conducted on January $21^{\text {st }}$ (Beach 2$)$ and $22^{\text {nd }}$ (Beach $3), 2015$ as well as August $17^{\text {th }}$ (Beach 1$), 18^{\text {th }}$ (Beach 2) and $19^{\text {th }}($ Beach 3), 2016 for approximately three hours per day. Macromollusks were represented by living specimens, fresh empty shells and a few shells with worn surfaces. All specimens were collected manually through active searches at different points of the three beaches during low tide, from the intertidal zone to shallow subtidal areas to a depth of about $1 \mathrm{~m}$. Worn or broken shells were usually. Individuals were collected with a proportional collecting effort from hard (e.g., surface, underneath and crevices) and soft (e.g., sand and gravel) substrate habitats of the reef ecosystems for approximately three hours at each beach. Algae were collected manually at different points of the study area and mollusks were subsequently separated from the algae. The collections were performed with the authorization of the Biodiversity Information and Authorization System (SISBIO 43234-2).
Some specimens (shells with soft parts) were preserved in $70 \%$ ethanol. Shells without soft parts were preserved dry. In the laboratory, mollusks were counted and identified based on shell morphology, primarily using Rios (2009), Tunnell et al. (2010) and Redfern (2013). The supraspecific classification was based on the World Register of Marine Species (WoRMS 2018).

Most of the material analyzed is deposited and available for study in the Coleção de Metazoários Aquáticos e Terrestres (COMAT [Aquatic and Terrestrial Metazoan Collection]) of the Unidade Academica de Ciências Exatas e da Natureza (UACEN [Academic Unit of Exact and Natural Sciences]) of the Centro de Formação de Professores (CFP [Professor Education Center]) of the Universidade Federal de Campina Grande (UFCG [Federal University of Campina Grande]) in the city of Cajazeiras, Paraíba, Brazil under the acronym: COMAT_MOL Malacological subcollection. Some individuals are deposited in the collection of biologist Geraldo Semer Pomponet Oliveira.

The species-accumulation curve was used to predict species richness based on the number of individuals captured. The biodiversity indices (ACE - Abundance-based Coverage Estimator; Chao 1 Abundance-Based Richness Estimator) were calculated using the EstimateS 9.1 program (Colwell 2013), which randomly computed accumulation curves.

\section{Results}

A total of 395 specimens from the reef ecosystems of Morro de São Paulo were collected and examined. Most were benthic macromollusks represented by living specimens and fresh empty shells. Ninety-eight species from the study site were identified (Table 1; Figures 2-10). The molluscan fauna consisted of 44 families and 84 species of gastropods (accounting for approximately $86 \%$ of the composition) (Figures 6-10), eight families and 13 species of bivalves (about $13 \%$ of the composition) (Figure 5) and one chiton (Figure 10D) (Table 1).

Species richness was numerically dominated by members of the subclass Caenogastropoda, which comprised about $66 \%$ of the species found at the study site (Figure 2). The other subclasses of Mollusca were present in much less representative groups (Figure 2). The main superfamilies of Caenogastropoda that stood out in terms of numbers of families and/or species richness were Tonnoidea (total of five families, six genera and 12 species), Buccinoidea (total of five families, nine genera and 11 species), Trochoidea (five families, five genera and seven species) and Conoidea (total of three families, seven genera and seven species) (Figure 3). Seven species of gastropods were also identified in Marginellidae, which is not yet ranked in WoRMS on the superfamily level (see MolluscaBase 2018) (Table 1). Other superfamilies of Caenogastropoda were represented by one (e.g., Calyptraeoidea and Mitroidea), two (e.g., Cerithioidea and Stromboidea), three (e.g., Cypraeoidea and Littorinoidea) or six species (e.g., Muricoidea) (Figure 3; Table 1). Most gastropods studied herein were collected on hard substrates (mainly beneath or between stones) from the reef ecosystem (Figure 10). In contrast, zebinids, marginellids (e.g., Granulina and Volvarina), aplustrids, aplysiids and pyramidellids were separated from algae in the reef areas. 


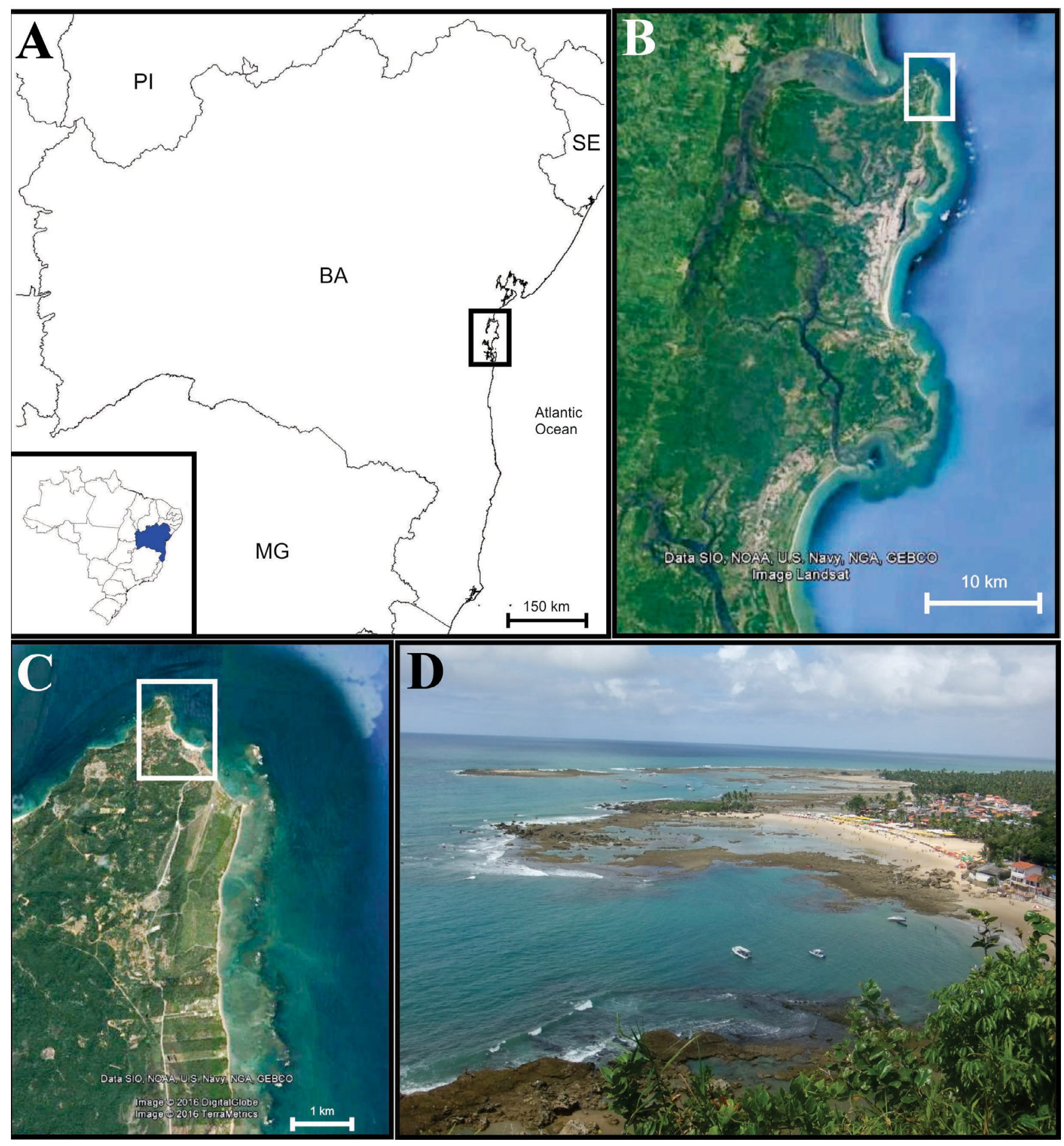

Figure 1. (A) Map of the state of Bahia (highlighted in blue in the northeastern Brazilian coast) showing the position of the Tinharé island; (B-C) Map of Tinharé island highlighting study sites in Morro de São Paulo; (D) Photo of Morro de São Paulo showing fringing reefs outcropping from Beaches 1, 2 and 3. 
Table 1. Mollusks associated with reef ecosystems and algae from the Morro de São Paulo. V= valve(s). SPE = specimen(s). * $=$ specimen(s) with soft parts.

\begin{tabular}{|c|c|c|c|c|}
\hline TAXA & SPECIES & SPE & BEACH & VOUCHER \\
\hline \multicolumn{5}{|l|}{ BIVALVIA } \\
\hline \multicolumn{5}{|l|}{ Pteriomorphia } \\
\hline \multirow[t]{2}{*}{ Arcidae } & Arca imbricata Bruguière, 1789 & $02 \mathrm{~V}$ & 01 & COMAT_MOL 03 \\
\hline & Barbatia candida (Helbling, 1779) & $14 \mathrm{~V}$ & 01 & COMAT_MOL 04 \\
\hline \multicolumn{5}{|l|}{ Mytiloidea } \\
\hline \multirow[t]{2}{*}{ Mytilidae } & Brachidontes exustus (Linnaeus, 1758) & 01 & 01 & COMAT_MOL 10 \\
\hline & Modiolus americanus (Leach, 1815) & 01 & 03 & COMAT_MOL 11 \\
\hline \multicolumn{5}{|l|}{ Pectinoidea } \\
\hline Chamidae & Chama sp. & 01 & 02 & COMAT_MOL 05 \\
\hline \multicolumn{5}{|l|}{ Lucinoidea } \\
\hline \multirow[t]{3}{*}{ Lucinidae } & Codakia orbicularis (Linnaeus, 1758) & $01 \mathrm{~V}$ & 01 & COMAT_MOL 07 \\
\hline & Divalinga quadrisulcata (d'Orbigny, 1846) & $04 \mathrm{~V}$ & 01 & COMAT_MOL 08 \\
\hline & Phacoides pectinatus (Gmelin, 1791) & $01 \mathrm{~V}$ & 03 & COMAT_MOL 09 \\
\hline \multicolumn{5}{|l|}{ Tellinoidea } \\
\hline \multirow[t]{2}{*}{ Tellinidae } & Austromacoma constricta (Bruguière, 1792) & $07 \mathrm{~V}$ & 02 & COMAT_MOL 13 \\
\hline & Eurytellina lineata (Turton, 1819) & $01 \mathrm{~V}$ & 02 & COMAT_MOL 14 \\
\hline \multicolumn{5}{|l|}{ Veneroidea } \\
\hline \multicolumn{5}{|c|}{ Patellogastropoda } \\
\hline \multicolumn{5}{|l|}{ Vetigastropoda } \\
\hline \multicolumn{5}{|l|}{ Fissurelloidea } \\
\hline Fissurellidae & Diodora cayenensis (Lamarck, 1822) & 01,01 & 03,02 & COMAT_MOL 21, 106 \\
\hline \multicolumn{5}{|l|}{ Trochoidea } \\
\hline Skeneidae & Parviturbo weberi Pilsbry \& McGinty, 1945 & 03 & 03 & COMAT_MOL 16 \\
\hline \multirow[t]{2}{*}{ Phasianellidae } & Eulithidium affine (C. B. Adams, 1850) & $02 *$ & 03 & COMAT_MOL 17 \\
\hline & Eulithidium bellum (M. Smith, 1937) & $11^{*}$ & 03 & COMAT_MOL 18 \\
\hline Calliostomatidae & Calliostoma gemmosum (Reeve, 1842) & 01 & 02 & COMAT_MOL 19 \\
\hline \multirow[t]{2}{*}{ Tegulidae } & Tegula hotessieriana (d'Orbigny, 1842) & 05 & 03 & COMAT_MOL 24 \\
\hline & Tegula viridula (Gmelin, 1791) & 07 & 03 & COMAT_MOL 25 \\
\hline Turbinidae & Lithopoma tectum (Lightfoot, 1786) & 08 & 03 & COMAT_MOL 26 \\
\hline \multicolumn{5}{|l|}{ Neritimorpha } \\
\hline Neritoidea & & & & \\
\hline Neritidae & Neritina virginea (Linnaeus, 1758) & 03 & 01 & COMAT_MOL 27 \\
\hline Caenogastropod & & & & \\
\hline Buccinoidea & & & & \\
\hline Buccinidae & Engina turbinella (Kiener, 1836) & 02 & 03 & COMAT_MOL 55 \\
\hline
\end{tabular}


Continuation Table 1.

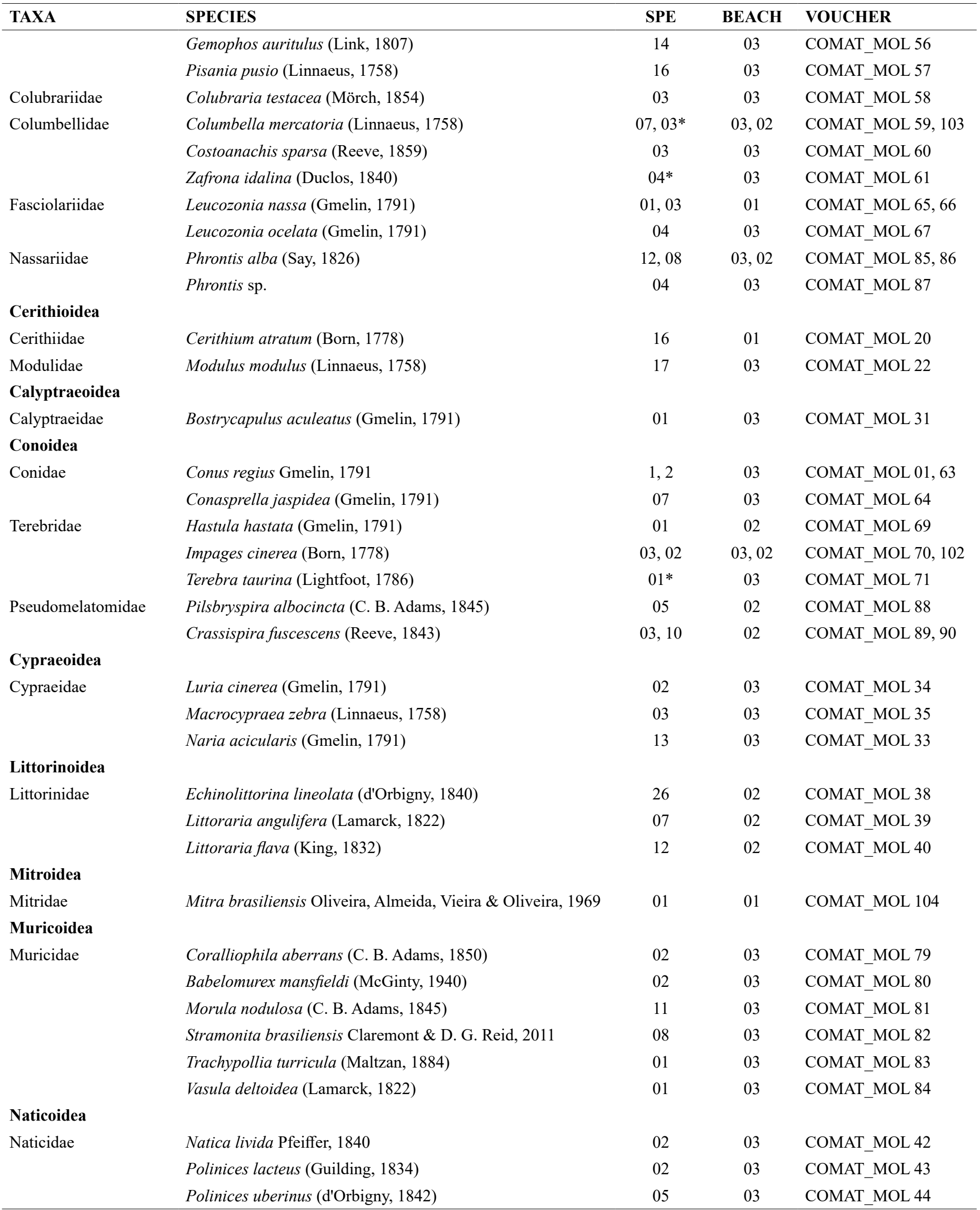


Continuation Table 1.

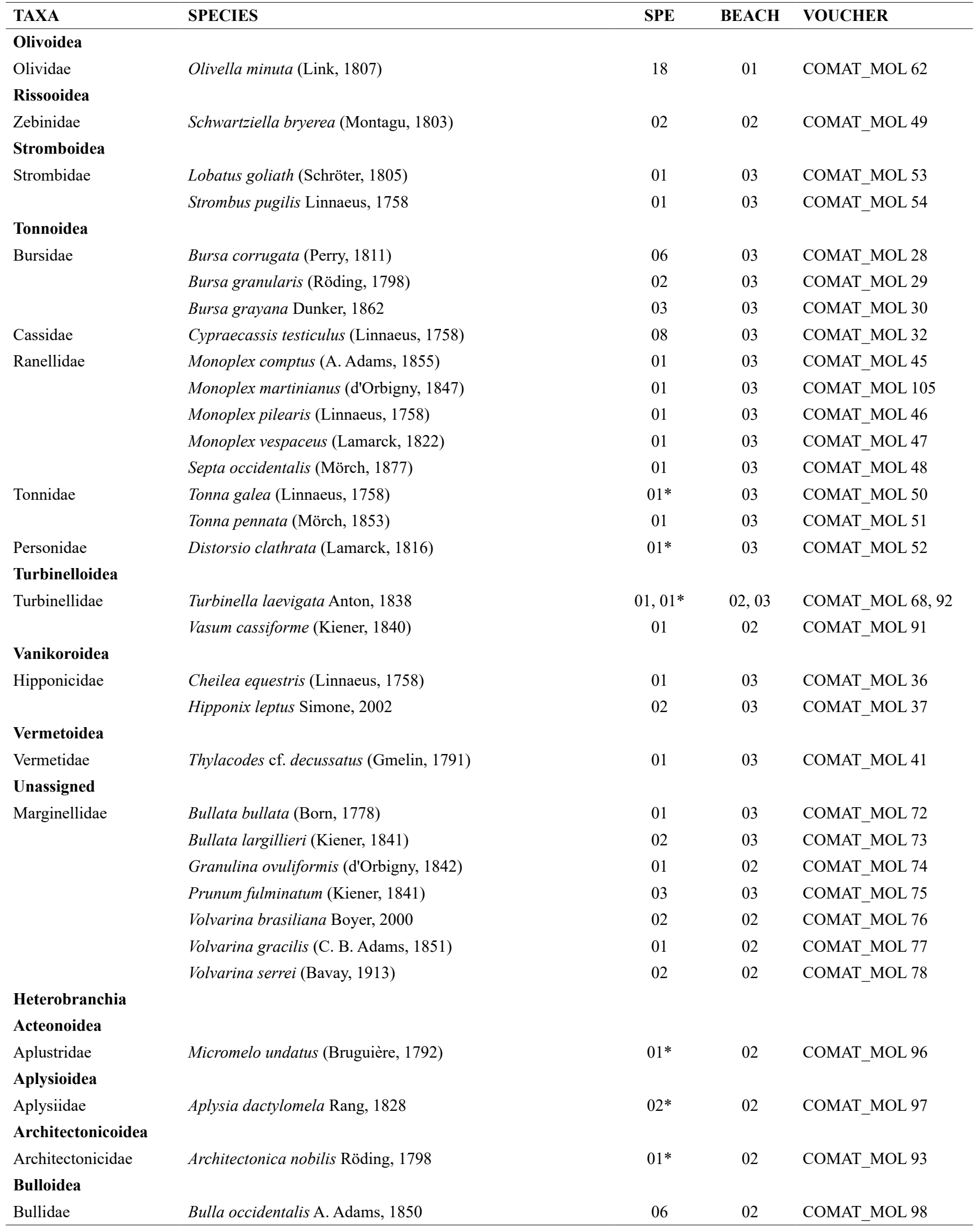


Continuation Table 1.

\begin{tabular}{|c|c|c|c|c|}
\hline TAXA & SPECIES & SPE & BEACH & VOUCHER \\
\hline \multicolumn{5}{|l|}{ Haminoeoidea } \\
\hline Haminoeidae & Atys guildingi Sowerby II, 1869 & 02 & 02 & COMAT_MOL 99 \\
\hline \multicolumn{5}{|l|}{ Philinoidea } \\
\hline Philinidae & Philine sagra (d'Orbigny, 1841) & 03 & 02 & COMAT_MOL 100 \\
\hline \multicolumn{5}{|l|}{ Pyramidelloidea } \\
\hline \multicolumn{5}{|c|}{ POLYPLACOPHORA } \\
\hline \multicolumn{5}{|l|}{ Neoloricata } \\
\hline \multicolumn{5}{|l|}{ Chitonoidea } \\
\hline Callistoplacidae & Ischnoplax pectinata (G. B. Sowerby II, 1840) & $04 *$ & 02 & COMAT_MOL 101 \\
\hline
\end{tabular}

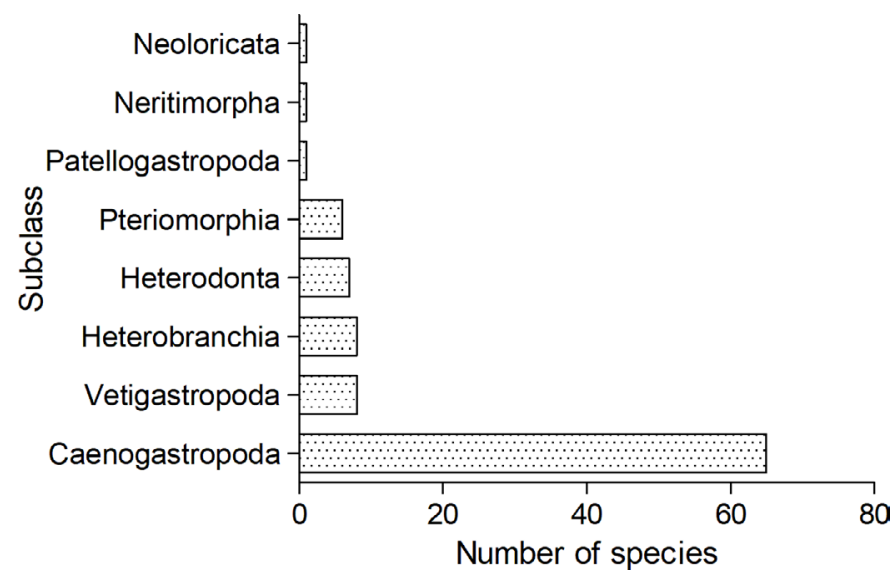

Figure 2. Species richness by subclasses of Mollusca collected from Morro de São Paulo.

The families with the greatest species richness were: Ranellidae (5), Muricidae (6) and Marginellidae (7). These families represented about $18 \%$ of the total number of species collected in the area. Families with only one species represented about $31 \%$ of the total richness (Figure 4 ).

Most of the gastropods found in the region were represented by empty shells in an excellent state of preservation. The exceptions were Micromelo undatus (Figure 8S), Tonna galea (Figure 9A), Architectonica nobilis (Figure 9B), Aplysia dactylomela (Figure 9C), Turbinella laevigata (Figure 9D), Distorsio clathrata (Figure 9E), Terebra taurina (Figure 9F), Conus regius (Figure 10A), Echinolittorina lineolata, Eulithidium affine, E. bellum, Impages cinerea, Leucozonia nassa, Littoraria angulifera, L. flava, Lottia subrugosa, Parviturbo weberi and Philine sagra, which were found living on different habitats of the reef ecosystems of Morro de São Paulo, such as the sediment (Figure 9), associated with gravel (Figure 9C), burrowing in sandy bottoms (Figure 9D), under rocks and/or cavities in rocks (Figure 10A-B). These gastropods were not abundant at the study site and were represented by a few specimens collected from the most protected areas and cryptic habitats of the reefs. Only Chama sp. (Figure 5C), Strombus pugilis (Figure 7L), Conus regius (Figure 7T) and Olivella minuta (Figure 8R) were represented by eroded shells.

Bivalvia was the second most diverse class, comprising approximately $13 \%$ of the mollusks found at the study site. Lucinoidea was the most numerous superfamily of Bivalvia, whereas other groups had one (e.g., Limoidea and Pectinoidea) or two species (e.g., Arcoidea and Mytiloidea) (Table 1; Figure 3). All species of bivalves were represented by empty shells, except Brachidontes exustus and Modiolus americanus, which were usually found in rock cavities.

Polyplacophora was the class of Mollusca with the lowest species richness at the study site. Ischnoplax pectinata was the only polyplacophoran and was found under rocks (Table 1; Figure 10D).

About $78 \%$ of the species of mollusks sampled from Morro de São Paulo were represented by empty shells. Gemophos auritulus, Pisania pusio, Columbella mercatoria, Phrontis alba, Cerithium atratum, Modulus modulus, Crassispira fuscescens, Naria acicularis, Echinolittorina lineolata, Littoraria flava, Morula nodulosa and Olivella minuta account for the largest proportion (approximately 47\%) of individuals collected (Table 1).

Only eleven species of mollusks represented by bivalves (limid, mytilid, arcid and lucinid) and gastropods (neritid, fasciolariid, neritid, mitrid and olivid) were found on Beach 1 (Table 1). Beach 2 had greater mollusk richness than that of Beach 1, with a total of four families and five species of bivalves, 16 families and 26 species of gastropods and the chiton Ischnoplax pectinata (Table 1). The highest mollusk richness was found on Beach 3, with two families and two species of bivalves and 28 families and 57 species of gastropods, highlighting the occurrence of columbellids, conids, muricids and ranellids (Table 1).

The two estimators used (ACE and CHAO 1) estimated 133 mollusk species for the region (Figure 11). Despite the reasonable number of species found at the study site (about $73.6 \%$ of the estimated total number), neither of the two estimators reached an asymptote, indicating an insufficient sampling effort and a number of species still to be discovered in the region. 


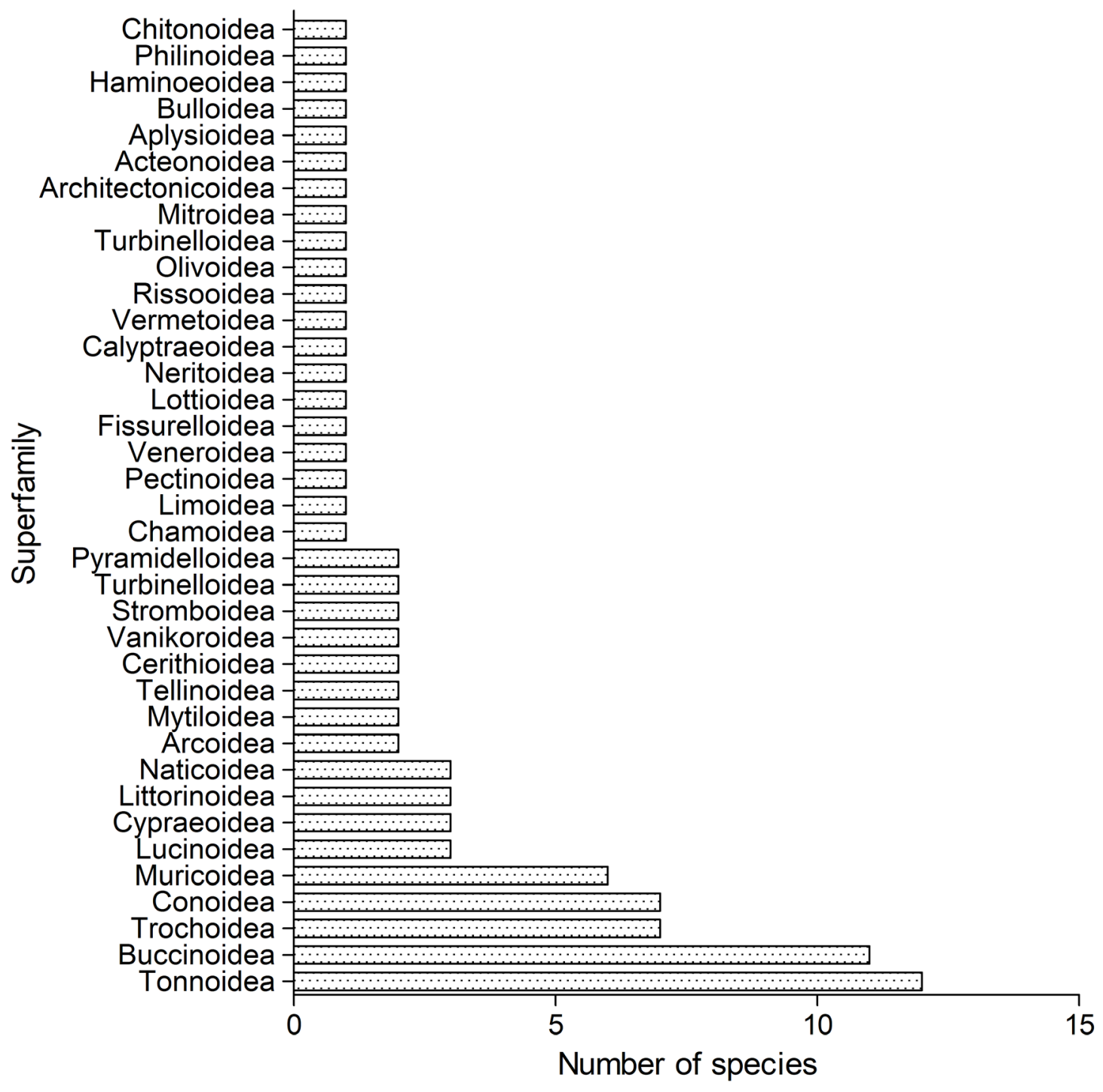

Figure 3. Species richness by superfamilies of Mollusca collected from Morro de São Paulo.

\section{Discussion}

The present work is the first effort to survey benthic mollusks of the reef ecosystems of Morro de São Paulo, which is an area of considerable ecological importance on the coast of the state of Bahia (northeastern Brazil). In this inventory, we describe predominantly epibenthic macromolusks collected from the intertidal to the subtidal shallow zone (to a depth of about $1 \mathrm{~m}$ ). Phacoides pectinatus, Austromacoma constricta, Eurytellina lineata and Anomalocardia flexuosa were among the few endobenthic mollusk (see Coan et al. 2000, Rios 2009) collected in Morro de São Paulo. Despite the limited sampling effort, we found a large number of mollusks on the beaches studied, which was expected (despite the impact of tourists at the study site); since Mollusca is the most diverse metazoan phylum of the marine environment (Bouchet et al. 2011) and because the coast of the Bahia is recognized for the considerable environmental complexity of its reef ecosystems, with a variety of habitats that favor the establishment of diverse invertebrate communities (Leão 1996, Castro et al. 2005a, b, Dutra et al. 2005).

The phylum Mollusca at the study site is composed mainly of ranellids, muricids and marginellids (Table 1). These families are among the most biodiverse in Brazilian waters, with species found in several habitat types (Rios 2009). Some families (e.g., Architectonicidae, Buccinidae, Calliostomatidae, Calyptraeidae, Chamidae, Colubrariidae, Fasciolariidae, Fissurellidae, Mitridae, Modulidae, Personidae, Spondylidae, Tellinidae, Terebridae and Vermetidae) had low to modest species richness in Morro de São Paulo. These groups are usually collected in deeper subtidal zones (depths greater than $1 \mathrm{~m}$ ) of the western Atlantic (see Diaz \& Puyana 1994, Rios 2009, Tunnell Jr. et al. 2010, Redfern 2013). The few individuals associated with reef 
Lima, S.F.B. et al.

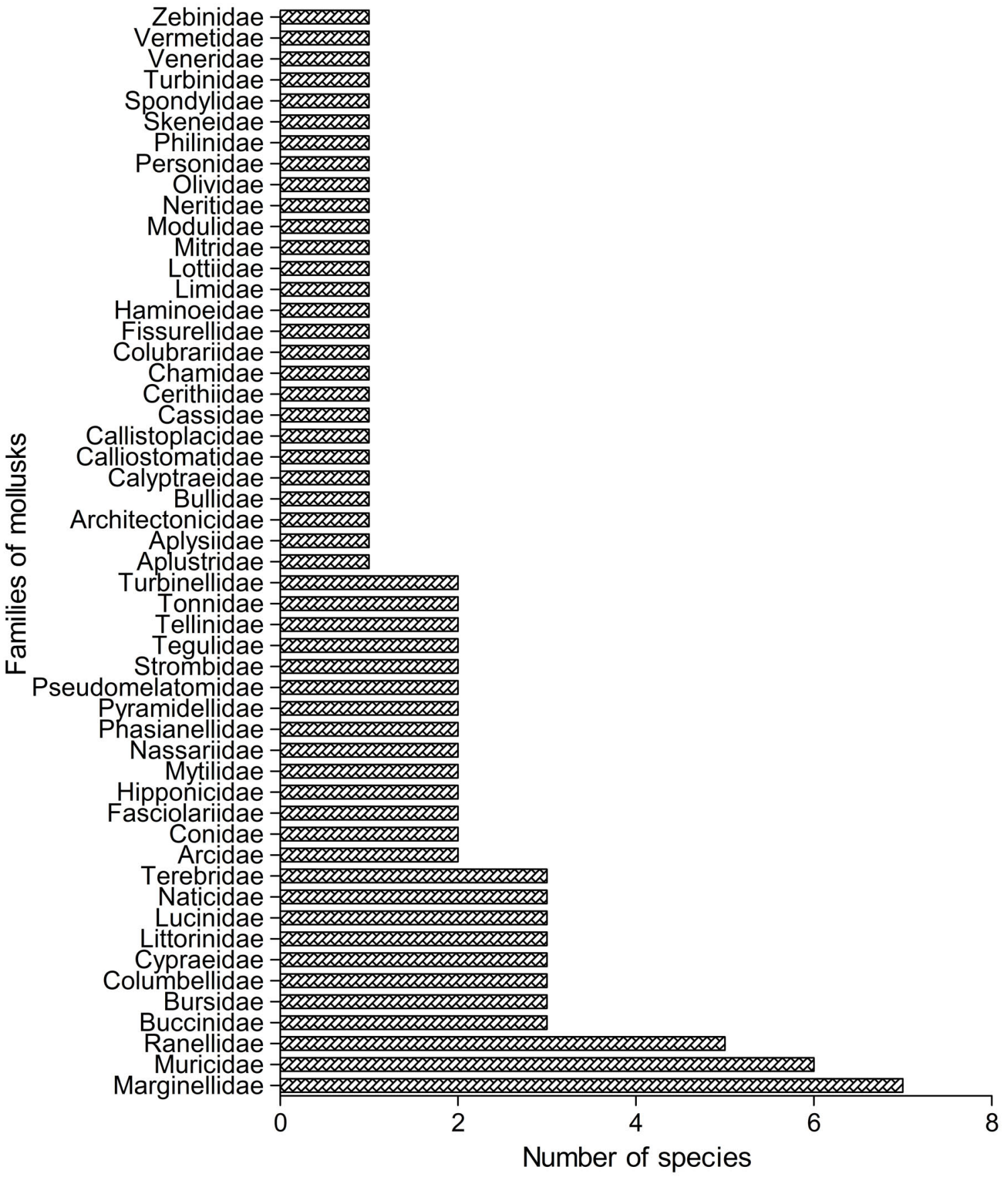

Figure 4. Species richness by families of Mollusca collected from Morro de São Paulo.

ecosystems in shallower areas of the study site are certainly severely impacted by the anthropogenic pressure on reefs and the direct collection of mollusks.

Marine mollusks were previously studied from important habitats on the continental shelf of Bahia: (1) the richness of mollusks found on the three beaches studied in Morro de São Paulo corresponded to about one third of the richness of benthic mollusks reported by Absalão (2005a) for the Abrolhos Bank. The following species were common to both the Abrolhos Bank reported by Absalão (2005a, b) and Morro de São Paulo reported in the present investigation: Diodora cayenensis, Parviturbo weberi, Calliostoma gemmosum, Rissoina bryerea, Strombus pugilis, Crepidula aculeata, Thais haemastoma (= Stramonita brasiliensis), Columbella mercatoria, Zafrona idalina, Nassarius albus (= Phrontis alba), Volvarina serrei, Granulina ovuliformis and Bulla occidentalis. Despite these common species, the mollusk composition identified in the present study and that reported by Absalão (2005a, b) for the Abrolhos Bank was somewhat different. Such differences in composition are attributed to environmental characteristics and the size of species found at both study sites. In the Abrolhos Archipelago, Absalão (2005a) surveyed 293 mollusks associated with a soft bottom and usually less 


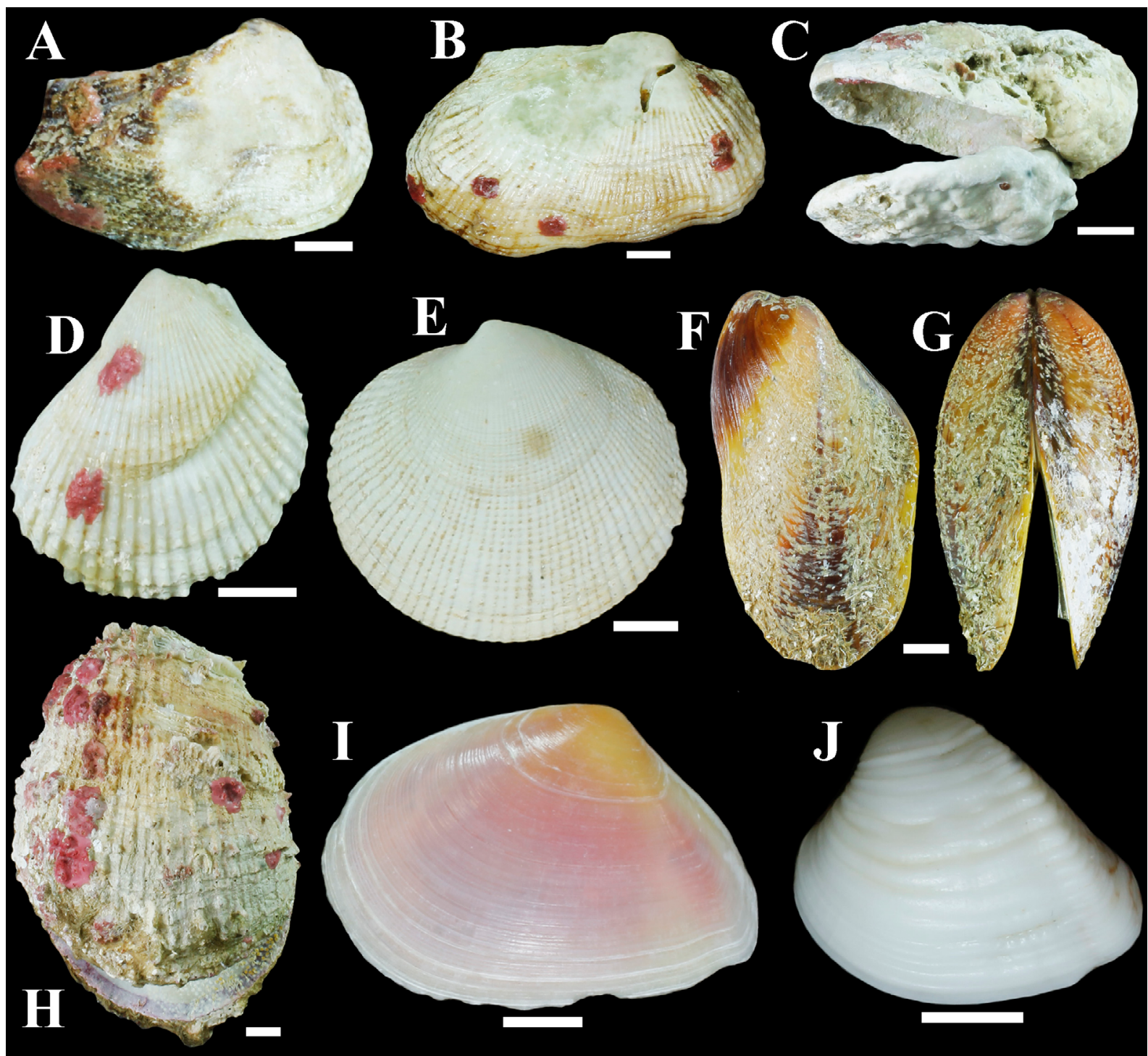

Figure 5. Macromollusks associated with reef ecosystems and algae from Morro de São Paulo: A. Arca imbricata, B. Barbatia candida, C. Chama sp., D. Lima caribaea, E. Codakia orbicularis, F-G. Modiolus americanus, H. Spondylus ictericus, I. Eurytellina lineata, J. Anomalocardia flexuosa. Scale bars: $5 \mathrm{~mm}$.

than $10 \mathrm{~mm}$ in length. In the present study, we prioritized the survey of macromolusks associated with hard substrates of the reef ecosystems. Distinct mollusk assemblages along the coast of Bahia, especially in the reef complex of the Abrolhos archipelago, may be much more common than we currently know, considering the environmental complexity of the extensive coastal zone; (2) in the Cachoeira River estuary, Ilhéus (Bahia), Ourives et al. (2011) found a few species of gastropods (e.g., phasianellid, neritid, cerithiid, olivid and zebinid) and bivalves (e.g., lucinid, tellinid and venerid) in common with those of the present investigation due to the focus of the study on macrofauna $(0.5-1.0 \mathrm{~mm})$ associated with sediments; (3) also from the Abrolhos Bank, Cunha et al. (2013) found a taxonomic richness of Mollusca (16 families and 24 species) associated with fronds of Dictyota spp., which is lower than the richness of families and species found in the present study. Only the gastropods Columbella mercatoria, Eulithidium affine and E. bellum were common to both studies. On the other hand, Cunha et al. (2013) found a composition of bivalves (composed of condylocardiids, crassatellids and mytilids) and part of the composition of gastropods (composed especially of caecids, columbellids, cylichnids, cystiscids, pyramidellids, scissurellids, vtrinellids and Nudibranchia) very different from the composition reported herein; (4) Luz \& Couto (2014) also studied the composition of mollusks from reef ecosystems on the coast of Bahia and found a total of 28 species in the reef environments studied, 11 of which also identified in the present study for Morro de São Paulo. Among all these surveys, the study by Luz \& Couto (2014) and the present investigation had the greatest richness of mollusks in areas of the continental shelf of Bahia, which demonstrates the importance of reef ecosystems as highly diversified environments. The significant discrepancies in the malacofauna composition between the present investigation and the studies by Absalão (2005a, b), Ourives et al. (2011), Cunha et al. (2013) and Luz \& Couto (2014) underscore the need for further research on invertebrate assemblages of the coast of Bahia to gain a better understanding of the characteristics of different habitats and species richness in each area. 


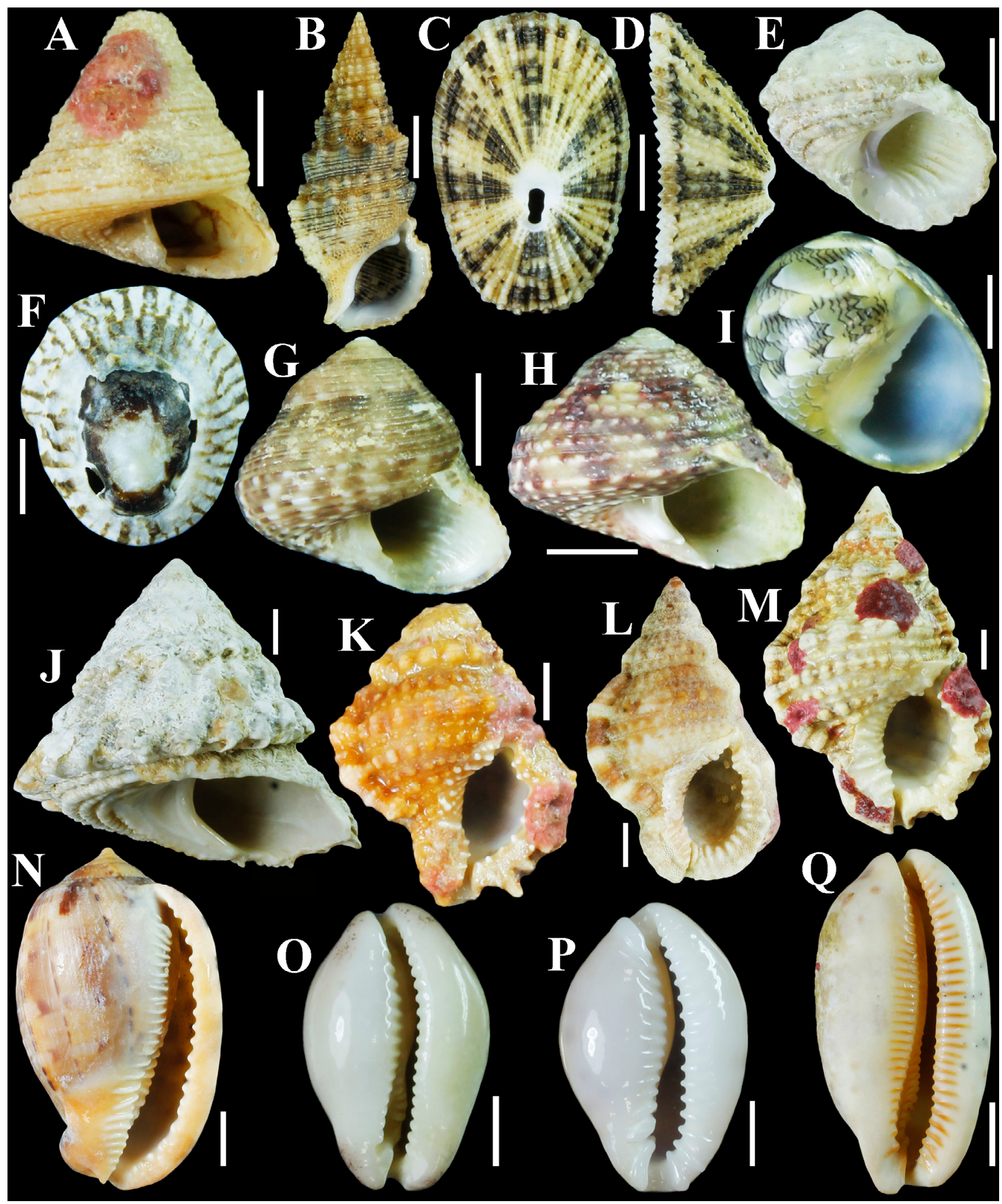

Figure 6. Macromollusks associated with reef ecosystems and algae from Morro de São Paulo: A. Calliostoma gemmosum, B. Cerithium atratum, C-D. Diodora cayenensis, E. Modulus modulus, F. Lottia subrugosa, G. Tegula hotessieriana, H. T. viridula, I. Neritina virginea, J. Lithopoma tectum, K. Bursa corrugata, L. B. granularis cubaniana, M. B. grayana, N. Cypraecassis testiculus, O. Luria cinerea, P. Erosaria acicularis marcuscoltroi, Q. Macrocypraea zebra. Scale bars: A-K. $5 \mathrm{~mm}, \mathrm{~N}$ and Q. $10 \mathrm{~mm}$. 


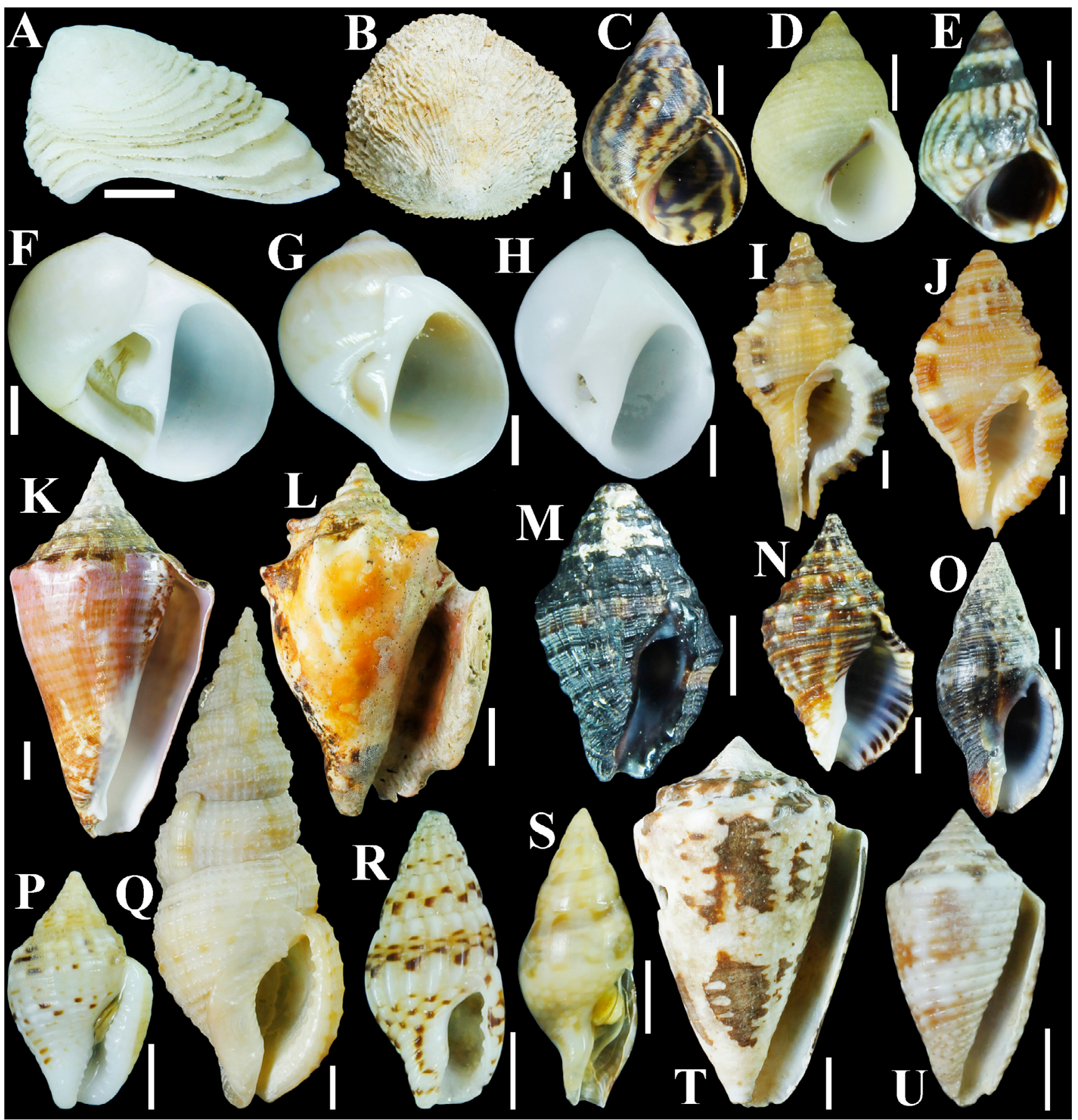

Figure 7. Macromollusks associated with reef ecosystems and algae from Morro de São Paulo: A. Hipponix leptus, B. Cheilea equestris, C. Littoraria angulifera, D. L. flava, E. Echinolittorina lineolata, F. Polinices uberinus, G. Natica livida, H. P. lacteus, I. Monoplex comptus, J. M. pilearis, K. Lobatus goliath, L. Strombus pugilis, M. Engina turbinella, N. Gemophos auritulus, O. Pisania pusio, P. Columbella mercatoria, Q. Colubraria testacea, R. Costoanachis sparsa, S. Zafrona idalina, T. Conus regius, U. Conus cf. jaspideus. Scale bars: A, H, I, M, Q. 3 mm, B, F, J, N, O, P, U. 5 mm, C-D. 4 mm, E, G, R, S. 2 mm, K, L, T. 10 mm. 


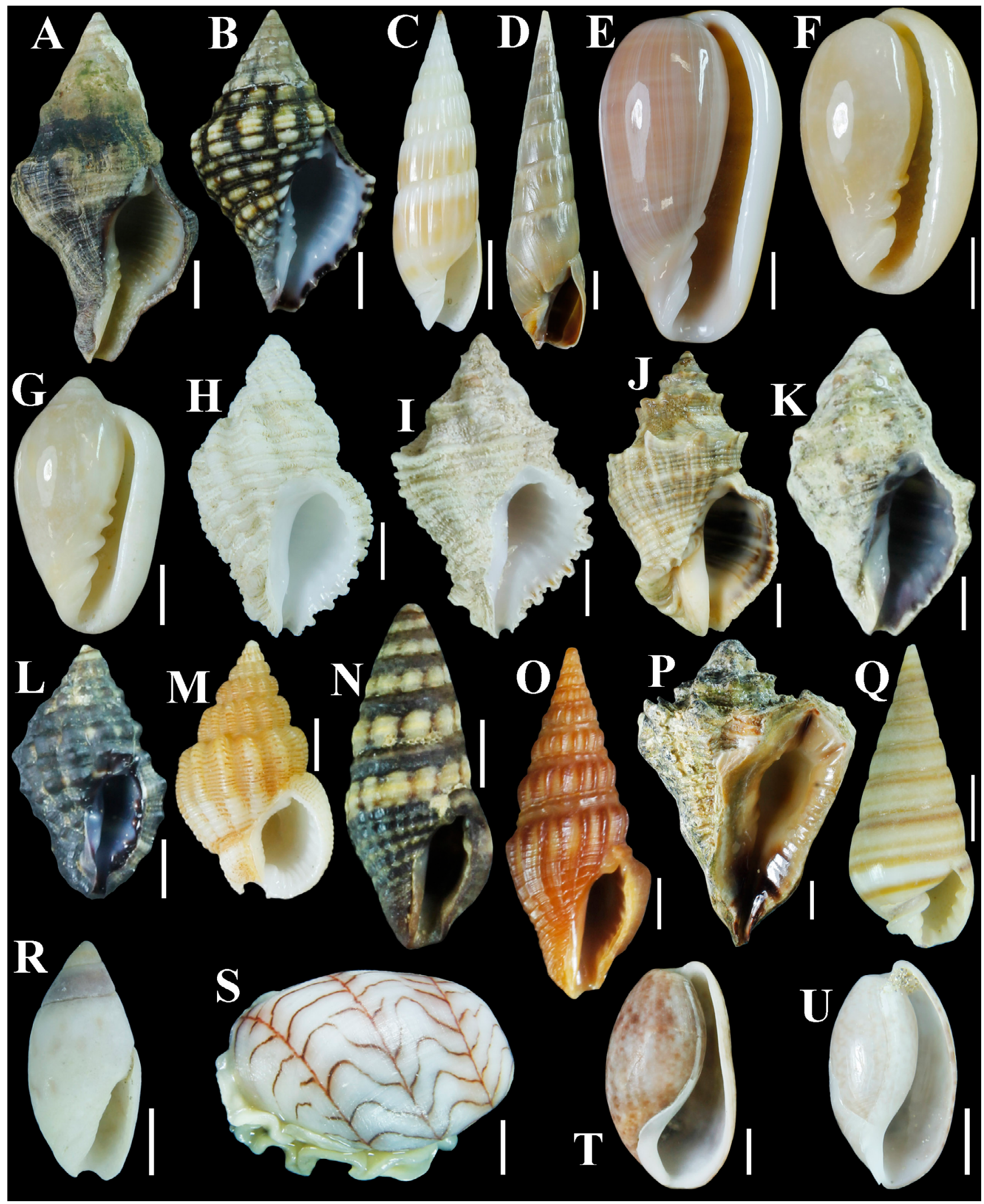

Figure 8. Macromollusks associated with reef ecosystems and algae from Morro de São Paulo: A. Leucozonia nassa, B. L. ocelata, C. Hastula hastata, D. Impages cinerea, E. Bullata bullata, F. B. largillieri, G. Prunum fulminatum, H. Coralliophila aberrans, I. Babelomurex mansfieldi, J-K. Stramonita brasiliensis, L. Trachypollia turricula, M. Phrontis alba, N. Pilsbryspira albocincta, O. Crassispira fuscescens, P. Vasum cassiforme, Q. Pyramidella dolabrata, R. Olivella minuta, S. Micromelo undatus, T. Bulla occidentalis, U. Atys guildingi. Scale bars: A-D, G, J, Q, T. 5 mm, E-F, P. 10 mm, H-I, K-N, R, U. 3 mm, S. 2 mm. 

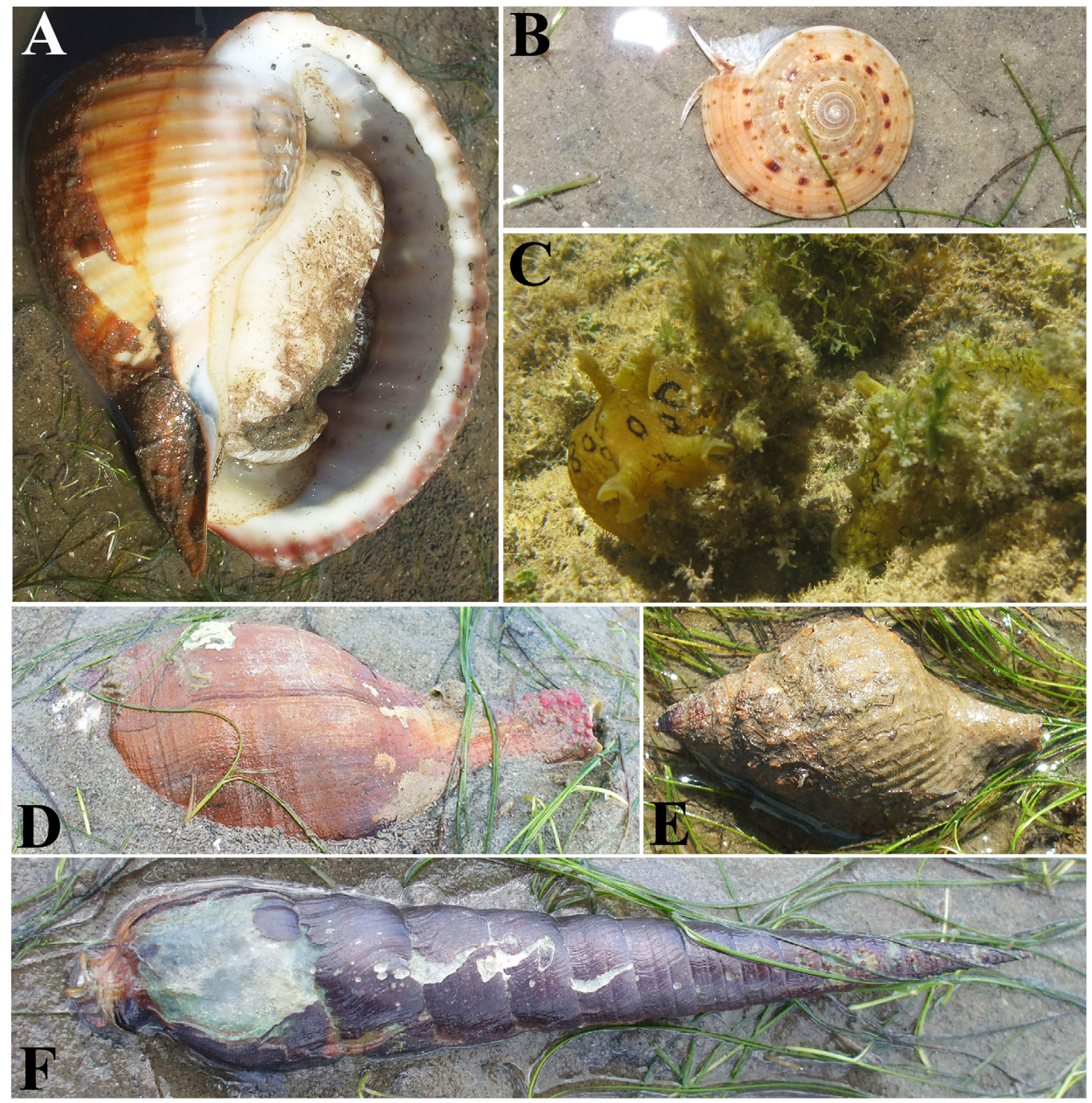

Figure 9. Macromollusks associated with reef ecosystems and algae from Morro de São Paulo: A. Tonna galea, B. Architectonica nobilis, C. Aplysia dactylomela, D. Turbinella laevigata, E. Distorsio clathrata, F. Terebra taurina.

Most of the mollusks found in Morro de São Paulo are well distributed along the Brazilian coast, despite no specific previous records for the state of Bahia (see Rios 2009). In contrast, Bullata bullata, B. largillieri, Calliostoma gemmosum, Hipponix leptus, Lobatus goliath, Turbinella laevigata, Vasum cassiforme, Prunum fulminatum and Volvarina serrei occur between northern and southeastern Brazil, especially in the northeastern portion and its oceanic islands (see Rios 2009). A number of species (e.g., Spondylus ictericus, Diodora cayenensis, Calliostoma gemmosum, Engina turbinella, Colubraria testacea, Columbella mercatoria, Zafrona idalina, Conus regius, Crassispira fuscescens, Macrocypraea zebra, Coralliophila aberrans, Morula nodulosa, Bursa corrugata, B. granularis, Cypraecassis testiculus and Distorsio clathrata) from 14 families (Table 1) have an extensive geographic distribution in the western Atlantic and co-occur in the reef ecosystems of Morro de São Paulo and the Caribbean (see Diaz \& Puyana 1994, Rios 2009, Tunnell Jr. et al. 2010, Redfern 2013).

In the present malacofauna survey, members of the families Bursidae, Conidae, Cypraeidae, Ranellidae, Tonnidae, Turbinellidae, Personidae and Strombidae merit particular attention due to the collection of specimens by artisanal fishermen in the region and surrounding coastal environment (Geraldo S. P. Oliveira - personal communication based on years of observation). Certainly, such families of macromollusks have undergone a considerable population decline in shallow waters at the study site as well as other regions on the coast of Bahia. Conids exemplify this very well, as this family has many species on the IUCN Red List of Threatened Species (IUCN 2018). 

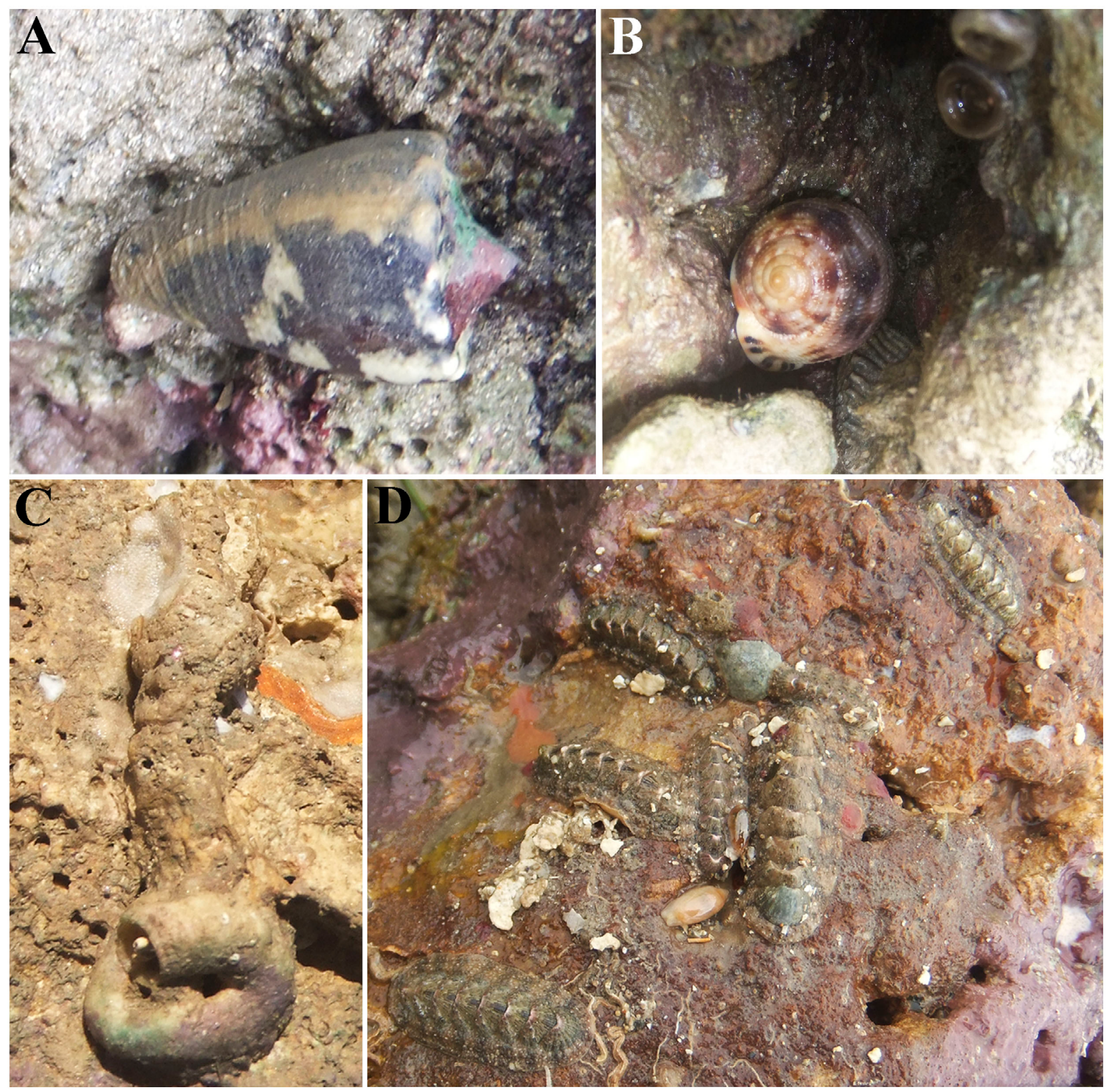

Figure 10. Macromollusks associated with reef ecosystems and algae from Morro de São Paulo: A. Conus regius, B. Cypraecassis testiculus, C. Thylacodes cf. decussatus, D. Ischnoplax pectinata.

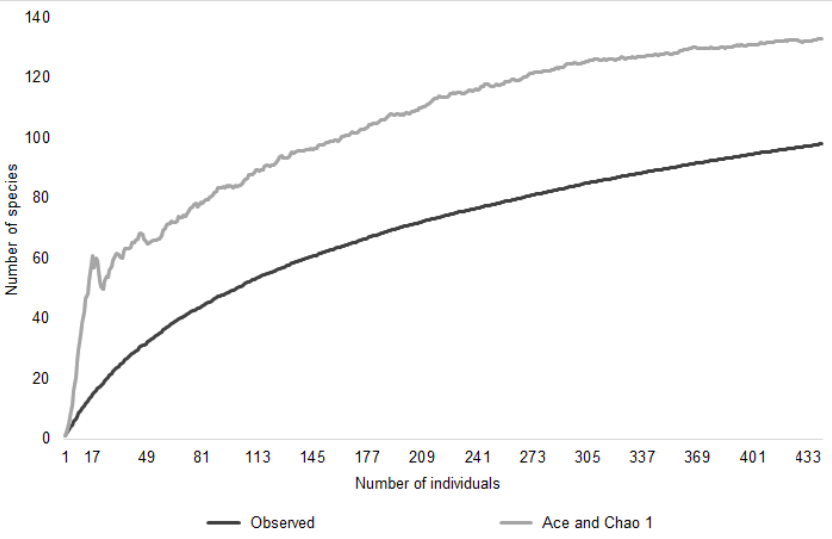

Figure 11. Mollusk species accumulation curve from reef ecosystems of Morro de São Paulo.
Anthropogenic pressure on mollusks and other groups of invertebrates is evident in the intertidal to subtidal zones on the coast of Bahia, as many individuals [e.g., conids (Gonçalves et al. 2017)] are collected for the purpose of selling the shells and as a food source (Geraldo S. P. Oliveira - personal communication based on years of observation).

The first and second beaches had lower mollusk richness indices and are more accessible to tourists. The highest mollusk richness was found on the third beach, which also has an influx of tourist activities, but apparently with less intensity. The reef ecosystems of this beach are slightly farther away from the sand strip and are separated by narrow pools that hinder access on the part of tourists.

Most species of mollusks found in the reef ecosystems of Morro de São Paulo were represented by empty shells, but many were in an excellent state of preservation (Figures 5-10). The macromollusks Architectonica nobilis, Conus regius, Distorsio clathrata, Impages 
cinerea, Leucozonia nassa, Terebra taurina, Tonna galea and Turbinella laevigata were among the few species found alive on the beaches studied. Architectonica nobilis, Conus regius and Distorsio clathrata are typically found in shallow waters associated with coral reefs, carbonaceous substrates and other types of substrate. In the reef ecosystems of the study site, however, such species are quite rare due to the anthropogenic impact, especially the collection of individuals by tourists or fishermen. This study also corroborates information that Architectonica nobilis, Distorsio clathrata, Terebra taurina and Tonna galea can be found on sandy substrates (see Diaz \& Puyana 1994, Rios 2009, Tunnell Jr. et al. 2010; Redfern 2013).

The present malacofauna inventory is the result of a rapid survey focusing predominantly on macromolluks living in shallow waters (depths to $1 \mathrm{~m}$ ) of the reef ecosystems of Morro de São Paulo. Therefore, an underestimation of mollusk richness at the study sites is to be expected, as demonstrated by the species accumulation curves. Despite this, we found a considerable number of species in the study area, which approached the mollusk richness predicted using the ACE and $\mathrm{CHAO}$ 1 models. The study area requires a greater sampling effort to complete the survey of the malacofauna, with the sampling of deeper areas of the reef ecosystems as well as collection efforts directed at micromollusks. Bouchet et al. (2002) point out the underestimation of mollusk richness in faunal surveys/inventories due to insufficient sample coverage of spatial heterogeneity and the emphasis on macromollusks in detriment to small mollusks and micromollusks in tropical coastal environments.

The majority of material studied was largely fresh dead shells, reflecting, to some extent, the species of mollusks living in the study site and adjacent reef areas. Absalão et al. (1999) demonstrated the feasibility of studying ecological diversity in a particular region of southeastern Brazil based on the shells of benthic macromolluks. Bouchet et al. (2002) also recognized part of the mollusks sampled in an area of New Caledonia based on empty shells due to their high probability of being part of the local richness studied.

The three beaches studied have small, shallow and relatively homogenous habitats in which the invertebrate community suffers different degrees of anthropogenic disturbances of the reef ecosystems. The alpha diversity presented herein for macromollusks could be effectively larger if actions to encourage responsible practices during recreational and leisure activities were implemented for the conservation of the reef ecosystems in the region. We believe that the richness of macromollusks in the ecosystems studied may extrapolate the projection predicted by the species accumulation curve.

The reef ecosystems of Morro de São Paulo certainly have even more diverse Mollusca fauna, as many families that typically occur in reef areas were absent from this inventory. Micromolluks represent a substantial component of these ecosystems and should receive special attention in future studies on the biodiversity of the group in this priority area for conservation on the coast of the state of Bahia, Brazil, for which species richness is virtually unknown.

\section{Acknowledgements}

The authors are grateful to M. Sc. Vinicius Queiroz Araújo and Licia Sales Oliveira (both from the Universidade de São Paulo, Instituto de Biociências) for their help in obtaining the literature; to Dr. Carmen
R. P. Guimarães (Universidade Federal de Sergipe, Centro de Ciências Biológicas e da Saúde, Departamento de Biologia) for allowing the use of the "Laboratório de Bentos Costeiro"; and the anonymous referees for their critical reviews, corrections and suggestions regarding the paper. This study was partially supported by the Brazilian fostering agency "Coordenação de Aperfeiçoamento de Pessoal de Nível Superior (CAPES)" and forms part of a project from "Fundação de Apoio à Pesquisa e a Inovação Tecnológica do Estado de Sergipe (Fapitec/SE)”.

\section{Author Contributions}

Silvio Felipe Barbosa Lima: Contribution for sampling of mollusks, to data collection, analysis and interpretation, manuscript preparation, critical revision, adding intellectual content.

Rudá Amorim Lucena: Contribution for sampling of mollusks, to data collection, analysis and interpretation, manuscript preparation, critical revision, adding intellectual content.

Geraldo Semer Pomponet Oliveira: Contribution for sampling of mollusks, to data collection, analysis and interpretation, manuscript preparation, critical revision, adding intellectual content.

Jéssica Prata: Contribution for sampling of mollusks, to data collection, analysis and interpretation, manuscript preparation, critical revision, adding intellectual content.

Bianca Vieira Lima: Contribution to data analysis and interpretation and contribution to manuscript preparation.

Evandro Cosmo Abreu: Contribution to data analysis and interpretation and contribution to manuscript preparation.

Luana Marina de Castro Mendonça: Contribution to data analysis and interpretation and contribution to manuscript preparation.

J. Weverton S. de Souza: Contribution to data analysis and interpretation and contribution to manuscript preparation.

\section{Conflicts of interest}

The authors declare that they have no conflict of interest related to the publication of this manuscript.

\section{References}

ABSALÃO, R.S. 2002. Three new species of Barleeidae (Mollusca, Gastropoda, Rissoidea) from Brazil. Zootaxa 56: 1-7.

ABSALÃO, R.S. 2005a. Soft-bottom molluses of the Abrolhos Bank. In A Rapid Marine Biodiversity Assessment of the Abrolhos Bank, Bahia, Brazil (G.F. Dutra, G.R. Allen, T. Werner, S.A. McKenna, eds). RAP Bulletin of Biological Assessment, Conservation International, Washington, volume 38, p. $82-86$.

ABSALÃO, R.S. 2005b. Molluscs recorded during the Abrolhos RAP survey. In A Rapid Marine Biodiversity Assessment of the Abrolhos Bank, Bahia, Brazil (G.F. Dutra, G.R. Allen, T. Werner, S.A. McKenna, eds). RAP Bulletin of Biological Assessment, Conservation International, Washington, volume 38, p.126-133.

ABSALÃO, R.S., PIMENTA, A.D., GOMES, R.S. \& CECCHETTI, F. 1999. Associações malacológicas dos substratos inconsolidados na Área de Proteção Ambiental do arquipélago de Santana, Macaé, Rio de Janeiro. In Ecologia dos Ambientes Costeiros do estado do Rio de Janeiro (S.H.G. Silva \& H.P. Lavrado, orgs), Oecologia Brasiliensis, Rio de Janeiro, p.273-289.

ALVES, O.F.S. \& CERQUEIRA, W.R.P. 2000. Echinodermata das praias de Salvador (Bahia, Brasil). Rev. Bras. Zool. 17: 543-553. 
ALVES, O.F.S., MANSO, C.L.C., ABSALÃO, R.S. \& PAIVA, P.C. 2006. Geoecology of sublittoral benthic communities in Todos os Santos Bay (Bahia, Brazil): Biotic e sedimentological diversity. J. Coastal Res. 39: 1152-1155.

BARROS, J.C.N. 1994. Moluscos recentes dos recifes costeiros e de sedimentos móveis intertidais de Pernambuco e da Bahia, Brasil. Cad. Ôm. Univers. Fed. Rur. Pernamb. 4: 35-77.

BARROS, F., HATJE, V., FIGUEIREDO, M.B., MAGALHÃES, W.F., DÓREA, H.S. \& EMÍDIO, E.S. 2008. The structure of the benthic macrofaunal assemblages and sediments characteristics of the Paraguaçu estuarine system, NE, Brazil. Estuar. Coast. Shelf Sci. 78: 753-762.

BOUCHET, P., LOZOUET, P., MAESTRATI, P. \& HEROS, V. 2002. Assessing the magnitude of species richness in tropical marine environments: exceptionally high numbers of molluscs at a New Caledonia site. Biol. J. Linn. Soc. 75: 421-436.

BOUCHET, P., BARY, S., HÉROS, V. \& MARANI, G. 2016. How many species of molluscs are there in the world's oceans, and who is going to describe them? In Tropical Deep-Sea Benthos (V. Héros, E. Strong E. \& P. Bouchet, eds). Muséum national d'Histoire naturelle, Paris, volume 29, p. 9-24.

BOUCHET, P., HÉROS, V., LOZOUET, P., MAESTRATI, P. \& VON COSEL, R. 2011. The marine Molluscs of Santo. In The Natural History of Santo (P. Bouchet, H. Le Guyader \& O. Pascal, eds). Muséum national d'Histoire naturelle, Paris, p. 421-431.

CASTRO, C.B., SEGAL, B., PIRES, D.O. \& MEDEIROS, M.S. 2005 a. Distribution and diversity of coral communities in the Abrolhos reef complex, Brazil. In A Rapid Marine Biodiversity Assessment of the Abrolhos Bank, Bahia, Brazil (G.F. Dutra, G.R. Allen, T. Werner \& S.A. McKenna, eds). RAP Bulletin of Biological Assessment, Conservation International, Washington, volume 38, p. 1-39.

CASTRO, C.B., SEGAL, B., PIRES, D.O. \& MEDEIROS, M.S. 2005b. Reef anthozoan and hydrocoral taxa recorded for the Abrolhos Area. In A Rapid Marine Biodiversity Assessment of the Abrolhos Bank, Bahia, Brazil (G.F. Dutra, G.R. Allen, T. Werner \& S.A. McKenna, eds). RAP Bulletin of Biological Assessment, Conservation International, Washington, volume 38, p. 96-97.

CASTRO, P. \& HUBER, M.E. 2013. Marine Biology. $9^{\circ}$ edition. McGraw Hill, New York.

COAN, E.V., VALENTICH-SCOTT, P. \& BERNARD, F.R. 2000. Bivalve seashells of western North America. Marine bivalve mollusks from Arctic Alaska to Baja California. Santa Barbara Museum of Natural History, Santa Barbara.

COLWELL, R.K. 2013. EstimateS: Statistical estimation of species richness and shared species from samples. Version 9. Available at: http://purl.oclc. org/estimates.

COSTA, JR.O.S., LEÃO, Z.M.A.N., NIMMO, M. \& ATTRILL, M.J. 2000. Nutrification impacts on coral reefs from northern Bahia, Brazil. Hydrobiologia. 440: 307-315.

CUNHA, T.J., GÜTH, A.Z. \& BROMBERG, S. 2013. Macrofauna associated with the brown algae Dictyota spp. (Phaeophyceae, Dictyotaceae) in the Sebastião Gomes Reef and Abrolhos Archipelago, Bahia, Brazil. Cont. Shelf Res. 70: 140-149.

DIAZ, M.J.M. \& PUYANA, H.M. 1994. Moluscos del Caribe Colombiano. Colciencias y Fundación Natura, Santafé de Bogota.

DUTRA, G.F., ALLEN, G.R., WERNER, T. \& MCKENNA, S.A. 2005. A Rapid Marine Biodiversity Assessment of the Abrolhos Bank, Bahia, Brazil. RAP Bulletin of Biological Assessment, Conservation International, Washington.

GONÇALVES, P.B., LIMA, S.F.B., OLIVEIRA, G.S.P. \& LUCENA, R.A. 2017. On the oviposition and egg masses of Conus regius (Neogastropoda: Conidae) from northeastern Brazil. Biota Neotrop. 17: e20170434.

HETZEL, B. \& CASTRO, C.B. 1994. Corais do Sul da Bahia. Editora Nova Fronteira, Rio de Janeiro.

INEMA. 2016. APA das Ilhas de Tinharé e Boipeba. Available at: http://www. inema.ba.gov.br/gestao-2/unidades-de-conservacao/apa/apa-ilhas-dotinhare-e-boipeba/. Access in: 07/09/2016.
IUCN. 2018. The IUCN Red List of Threatened Species. Version 2018-1. Available at: www.iucnredlist.org. Access in: 18/08/2018.

KIKUCHI, R.K.P., OLIVEIRA, M.D.M., LEÃO, Z.M.A.N., SILVA, R.M. \& MARTINS, P.M.R. 2008. Os Recifes de Tinharé-Boipeba-Camamu, Bahia. Rio Oil \& Gas Expo and Conference: 1-8.

LEÃO, Z.M.A.N. 1996. The coral reefs of Bahia: morphology, distribution and the major environmental impacts. An. Acad. Bras Cienc. 68: 439-452.

LEÃO, Z.M.A.N. 2002. Abrolhos, BA - O complexo recifal mais extenso do Atlântico Sul. In Sítios Geológicos e Paleontológicos do Brasil (C. Schobbenhaus, D. Campos, E. De Queiroz, M. Winge, \& M. Berbert-Born, eds). DNPM/CPRM/SIGEP, p. 345-359.

LEÃO, Z.M.A.N. \& GINSBURG, R.N. 1997. Living reefs surrounded by siliciclastic sediments: the Abrolhos coastal reefs, Bahia, Brazil. Proceedings of the 8th International Coral Reef Symposium, 2: 1767-1772.

LEÃO, Z.M.A.N. \& KIKUCHI, R.K.P. 2001. The Abrolhos Reefs of Brazil. In Coastal Marine Ecossystem of Latin America (U. Seeliger, L.D. Lacerda \& B. Kjerfve, orgs). Springer-Verlag, Berlin, volume 144, p. 83-96.

LEÃO, Z.M.A.N., KIKUCHI, R.K.P., FERREIRA, B.P., NEVES, E.G., SOVIERZOSKI, H.H., OLIVEIRA, M.D.M., MAIDA, M., CORREIA, M.D. \& JOHNSSON R. 2016. Brazilian coral reefs in a period of global change: A synthesis. Braz. J. Oceanogr. 64: 97-116.

LIMA, S.F.B., SANTOS, F.N. \& ABSALÃO, R.S. 2013. New Species of Caecum (Caenogastropoda: Rissooidea: Caecidae) from the Atlantic Coast of South America (Brazil) with a Description of the Protoconch and Growth Stages. Zool. Sci. 30: 767-778.

LUCENA, R.A. \& CHRISTOFFERSEN, M.L. 2017. Pycnogonida (Arthropoda) from the Abrolhos Archipelago, Brazil, including a new species of Callipallene Flynn, 1929. Mar. Biodivers., 47: 461-468.

LUZ, Í.O. \& COUTO, E.C.G. 2014. Moluscos em piscinas no platô recifal de Coroa Vermelha (litoral sul da Bahia, Brasil). Enciclopédia Biosfera. 10: 2360-2367.

MAZZEI, E.F., BERTONCINI, A.A., PINHEIRO, H.T., MACHADO, L.F., VILAR, C.C., GUABIROBA, H.C., COSTA, T.J.F., BUENO, L.S., SANTOS, L.N., FRANCINI-FILHO, R.B., HOSTIM-SILVA, M. \& JOYEUX, J.-C. 2016. Newly discovered reefs in the southern Abrolhos Bank, Brazil: Anthropogenic impacts and urgent conservation needs. Mar. Pollut. Bull. 114(1): 123-133.

MMA. 2010. Panorama da conservação dos ecossistemas costeiros e marinhos no Brasil. MMA/SBF/GBA, Brasília.

MOLLUSCABASE. 2018. Marginellidae J. Fleming, 1828. Available at: http://www.marinespecies.org/aphia.php? $\mathrm{p}=$ taxdetails\&id=23025. Access in: $30 / 06 / 2018$,

MORETZSOHN, F., TUNNELL Jr., J.W., LYONS, W.G., BAQUEIRO CÁRDENAS, E.B., BARRERA, N., ESPINOSA, J., GARCÍA, E.F., ORTEA, J. \& REGUERO, M. 2009. Mollusca: Introduction. In Gulf of Mexico-Origins, Waters, and Biota. Biodiversity (D.L. Felder \& D.K. Camp, eds). Texas A\&M University Press, College Station, Texas, p. 559-564.

MOURA, C.W.N., ALVES, A.M., SANTOS, A.A., ALMEIDA, W.R., MONIZ BRITO, K.L., OLIVEIRA, I.S., FREITAS, N.S., OLIVEIRA, I.B. \& RAMOS, G.J.P. 2015. Checklist of phytobenthos from Boipeba Island, Bahia, Brazil, emphasizing the morphological features of Nitophyllum punctatum (Rhodophyta, Ceramiales). Check List. 11: 1704.

OURIVES, T.M.S., RIZZO, A.E. \& BOEHS, G. 2011. Composition and spatial distribution of the benthic macrofauna in the Cachoeira River estuary, Illéus, Bahia, Brazil. Rev. Biol. Mar. Oceanogr. 46: 17-25.

PAIM, F.G., GUERRAZZI, M.C. \& BORGES, M. 2015. Descriptive and illustrated diagnosis of Ophiuroidea fauna (Echinodermata) in the shallow waters of North-eastern Brazil. Mar. Biodivers. Rec. 8: 1-17.

PAZ, J.R.L., OLIVEIRA, M.J. \& SILVA, P.P. 2012. Levantamento da malacofauna bentônica de costões rochosos do mesolitoral da praia de Plataforma, Bahia. Candombá. 8: 72-80.

QUEIROZ, V. \& SALES, L. 2013. On the spawning of Melanella eburnea (Gastropoda, Eulimidae). Strombus. 20: 27-29. 
QUEIROZ, V. \& SALES, L. 2016. A new color pattern for the ascidiansymbiontic Lamellaria mopsicolor (Mollusca: Caenogastropoda) in northeastern Brazil, with a discussion of its symbiotic lifestyle. Pan-Am. J. Aquat. Sci. 11: 123-129.

QUEIROZ, V., SALES, L., SAMPAIO, C.L.S., NEVES, E.G. \& JOHNSSON, R. 2011. Gastropoda, Caenogastropoda, Eulimidae, Annulobalcis aurisflamma Simone and Martins, 1995: First record to northeastern Brazil. Check List. 7: 645-647.

QUEIROZ, V.; SOUZA, L.S.; PIMENTA, A.D.; CUNHA, C.M. 2013. New host records to Melanella (Caenogastropoda: Eulimidae) from the Brazilian coast. Mar. Biodivers. Rec. 6: 1-5.

REDFERN, C. 2013. Bahamian seashells: 1161 Species from Abaco, Bahamas. BahamianSeashells.com, Inc., Florida.

RIOS, E.C. 2009. Compendium of Brazilian Sea Shells. Evangraf, Rio Grande.

RODRÍGUEZ-RAMÍREZ, A., BASTIDAS, C., CORTÉS, J., GUZMÁN, H., LEÃO, Z., GARZÓN-FERREIRA, J., KIKUCHCHI, R., FERREIRA, B.P., ALVARADO, J.J., JIMÉNEZ, C., FONSECA, A.C., SALAS, E., NIVIA, J., FERNÁNDEZ, C., RODRÍGUEZ, S., DEBROT, D., CRÓQUER, A., GIL, D., GÓMEZ, D.I., NAVAS-CAMACHCHO, R., REYES-NIVIA, M.C., ACOSTA, A., ALVARADO, E., PIZARRO, V., SANJUAN, A., HERRÓN, P., ZAPATA, F.A., ZEA, S., LÓPEZ-VICTORIA, M. \& SÁNCHCHEZ, J.A. 2008. 20. Status of Coral Reefs and Associated Ecosystems in Southern Tropical America: Brazil, Colombia, Costa Rica, Panamá and Venezuela. In Status of Coral Reefs of the World 2008 (C. Wilkinson, org.). GCRMN and Reef ans Rainforest Research Centre, Townsville, volume 1, p. 281-294.
SALES, L., QUEIROZ, V. \& MIGOTTO, A.E. 2016. Rediscovery of Okenia impexa Marcus 1957 on the Brazilian coast: the first image of a living specimen from Brazil. Spixiana. 39: 203-204.

SALES, L., QUEIROZ, V., PADULA, V., NEVES, E.G. \& JOHNSSON, R. 2013. New records of nudibranchs (Mollusca: Gastropoda) from Bahia State, Northeastern Brazil. Check List. 9: 689-691.

SALES, L., DELGADO, M., QUEIROZ, V., PADULA, V., SAMPAIO, C.L.S. \& JOHNSSON, R. 2011. First record of Flabellina dana Millen and Hamann, 2006 (Mollusca: Nudibranchia) in the South Atlantic Ocean. Check List. 7: $880-882$

TUNNELL, Jr.J.W., ANDREWS, J., BARRERA, N.C. \& MORETZSOHN, F. 2010. Encyclopedia of Texas Seashells: Identification, Ecology, Distribution and History. College Station, Texas A \& M University Press, Texas.

WoRMS (2018). Mollusca. Available at: http://www.marinespecies.org/aphia. php? $\mathrm{p}=$ taxdetails $\& i d=51$. Access in: 2018-04-01.

Received: 18/02/2019

Revised: $13 / 08 / 2019$

Accepted: 19/08/2019

Published online: 10/10/2019 